\title{
DRUG RESISTANT TUBERCULOSIS
}

\author{
Brig SP KALRA*, Col SC TEWARI', \\ Lt Gen R JAYASWAL", AvSM
}

MJAFI 1997; $53:$ 157-158

KEYWORDS: Drug resistance; Tuberculosis; Epidemiology.

W e celebrated on March 24th, the Intemational Tuberculosis Day. It was indeed a day dedicated to promote awareness, knowledge and motivation to fight against tuberculosis world wide.

On this very day in 1882 , thirty six members of the Society of Physiology in Berlin sat listening to Robert Koch, who was presenting his unassailable data proving that PHTHISIS (as the disease was then known) was caused by the bacillus he had isolated. Not a soul stirred and they listened with rapt silence. As Koch finished his oration for minutes together there was no sound, as if time had frozen, and then suddenly the hall erupted with an applause that was never heard nor seen before.

Years rolled by with further discoveries in all aspects of the disease, i.e. pathogenesis and pathology, transmission, diagnostic methods and finally in the mid 20th century, chemotherapy. Physicians and the world community thought that the battle against the disease, which spared neither the high and mighty nor the poorest of the poor, was won. It is a sad commentary on our medical and social practices of dealing with such major killers of mankind, that today we face a more daunting challenge as will be evident from the titles of a few recent articles in scientific joumals all around the world: "Drug Resistant Tuberculosis - Problems on the Horizon" [1], "The White Plague: Down and Out or Up and Coming?" [2], "The return of an old enemy, (The Empire strikes back)" [3]. "Tuberculosis, commentary on a re-emergent killer" [4], "Drug resistance in India - A tragedy in the making" [5].
The global scenario of the disease itself is depressing. As per WHO data, 1 in 3 living persons in this world are infected with tubercle bacilli; eight million new cases occur every y'ear along with 2.9 million deaths; by the year 2000 AD there will be 10.3 million new cases every year with 3-7 million deaths, i.e. 90 million more cases than we have today. The sharply rising case fatality rates are mostly due to infection by drug resistant organisms and HIV-related tuberculosis world wide.

To paint an accurate picture of multi drug resistant tuberculosis (MDRTB) is not possible because hardly any country, including ours where the burden of the disease is maximum, have any reliable surveillance programmes [6]. However if any clue can be taken from the advanced countries like the USA, the burden is a very major cause of concern $[2,4]$. One such study [7] in New York involving 466 samples in a single month demonstrated a multi-drug resistant phenotype in 19 per cent of isolates and found that majority of these patients had received previous therapy. Here lies the great responsibility of correct and adequate therapy by all concemed in treating this disease so that emergence of MDRTB strains are $r$ 'nimised. The resistance of Mycobacterium tube culosis reflects the quality of chemotherapy use' in the community [8]. Elsewhere in this issue iewari et al have reviewed the problems of MDRTB and discussed its management strategies while another paper by Rosha et al provides a clinical account of their experience in treating patients with MDRTB $[9,10]$.

The responsibility for spread of this "Captain of

Professor and Head, Dept of Medicine. "Commandant. Armed Forces Medical College, Pune $411040,{ }^{+}$Senior Adviser. Professor and Head, Dept of Resp Medicine, MH (CTC) Pune. 
all Men of Death" is rightly to be shared by the world community in general and especially by the developed countries and also many developing ones, for squandering large amounts of money and resources on inconsequential medical care programmes. This has been very well put by Reichmann in 1986 in an article titled "How to Ensure the Continued Resurgence of Tuberculosis" [11].

\section{REFERENCES}

1. Omerod LP. Drug Resistant Tuberculosis - Problems on the Horizon. Thorax 1993; 48: 957-8.

2. Murray JF. The White Plague: Down and Out or Up and Coming? Am Rev Respir Dis 1989; 140; 1788-95.

3. Collins FM. Tuberculosis, the retum of an old enemy. Crit Rev Microbiol 1993; 19: 1-16.

4. Bloom BR, Murry CJ. Tuberculosis: Commentary on a re-emergent killer. Science 1992; 257: 1055-64.

5. Jain NK. Drug Resistance in India - A tragedy in the making. Indian J Tub 1992; 39: 145-7.
6. Tuberculosis progranme. WHO Geneva and International Union against tuberculosis and lung diseases. (iuidelines for surveillance for survcillance against tuberculosis. Second report. Tubercle 1980; 61 : 59-69.

7. Frieden TR, Sterling T, Pablo MA, et al. The emergence of drug resistant tuberculosis in New York City. New Engl J Med 1993; 328: $521-6$

8. Chaulet P. Boulahbal F, Grosset I. Surveillance for drug resistance against tiberculosis control. Why and How? Tubercle and Lung Diseases 1995: 76: 487-92.

9. Tiwari SC, Kalra SP. Dangwal S. Clsatterji RS. Multi drug resistant tuberculosis (MDRTB) - biomechanism, epidemiology and management strategies. Medical Journal Armed Forces India 1997; $53: 207-13$

10. Rosha D, Dandona PK, Jayaswal R. Multi drug resistant tuberculosis (MDRTB) - biomechanism, epidemiology and management strategies. Medical Journal Armed Forces India $1997 ; 53: 159-62$

11. Reichman LB. How to ensure the continued resurgence of tuberculosis. Lancet 1996: 8995: 175-7. 